\title{
Changing Sources of Farm Credit
}

\author{
Speesb by Darryl R. Francis, President, \\ Federal Reserve Bank of St. Louis, \\ At Chemical Dealers" "Independence Day" Meeting \\ Tan-Tar-A, Lake of the Ozarks, \\ Osage Beach, Missouri, December 13,1967
}

\begin{abstract}
I
HAVE been requested to discuss the changing sources of farm credit and means whereby businessmen can influence the paying habits of farmers. It is to the first item, namely, the changing sources of farm credit, that I would like to direct most of this discussion. Then, based on some conclusions relative to farm credit sources and the changing structural pattern of agriculture, I shall make some concluding comments on farm debt repayment.

At the beginning I might say that outside credit has played a relatively minor role in finanoing our agricultural plant. Most farms have been largely financed internally. Much of the physical capital as land clearing, drainage, fencing, and building was produced on the farm by the farm family. Only in the past few decades has a large portion of farm capital been acquired through off-farm purchases, and many of these capital inputs were covered by savings of the farm family.
\end{abstract}

Since 1948 credit used by farmers has not exceeded 17 per cent of total farm assets, and in the 6 years prior to 1954 the volume of farm oredit outstanding was less than 10 per cent of total farm assets (Table 1). In comparison, credit used by manufacturing establishments has accounted for a much greater portion of total assets. During the period 1948 to 1967 , inclusive, total liabilities of all manufacturing corpora" tions, excluding newspapers, on the basis of book value never fell below 28 per cent of total assets. Furthermore, in 1967 debt exceeded 40 per cent of the assets of these firms.

Atthough the spread in debt-to-asset ratios of farms and manufacturing firms remains quite wide, it has declined steadily since 1948. At that time debts totaling 31.2 per cent of assets in manufacturing were 4.3 times the per cent of debts to assets in agriculture. Since then the per cent of debts to assets in both industries has risen steadily. However, the per cent in agriculture rose at a greater rate than in manufactur- ing, and in 1967 the per cent of debts to assets in manufacturing was only 2.4 times that in agriculture.

Internal financing of agriculture has thus declined substantially since 1948 relative to total farm capital, and credit has played an increasing role in farm capital accumulation.

As implied in the subject of this discussion, farm credit sources are changing. The change, however, has been gradual rather than revolutionary. It is when we view farm credit over the past half century that major

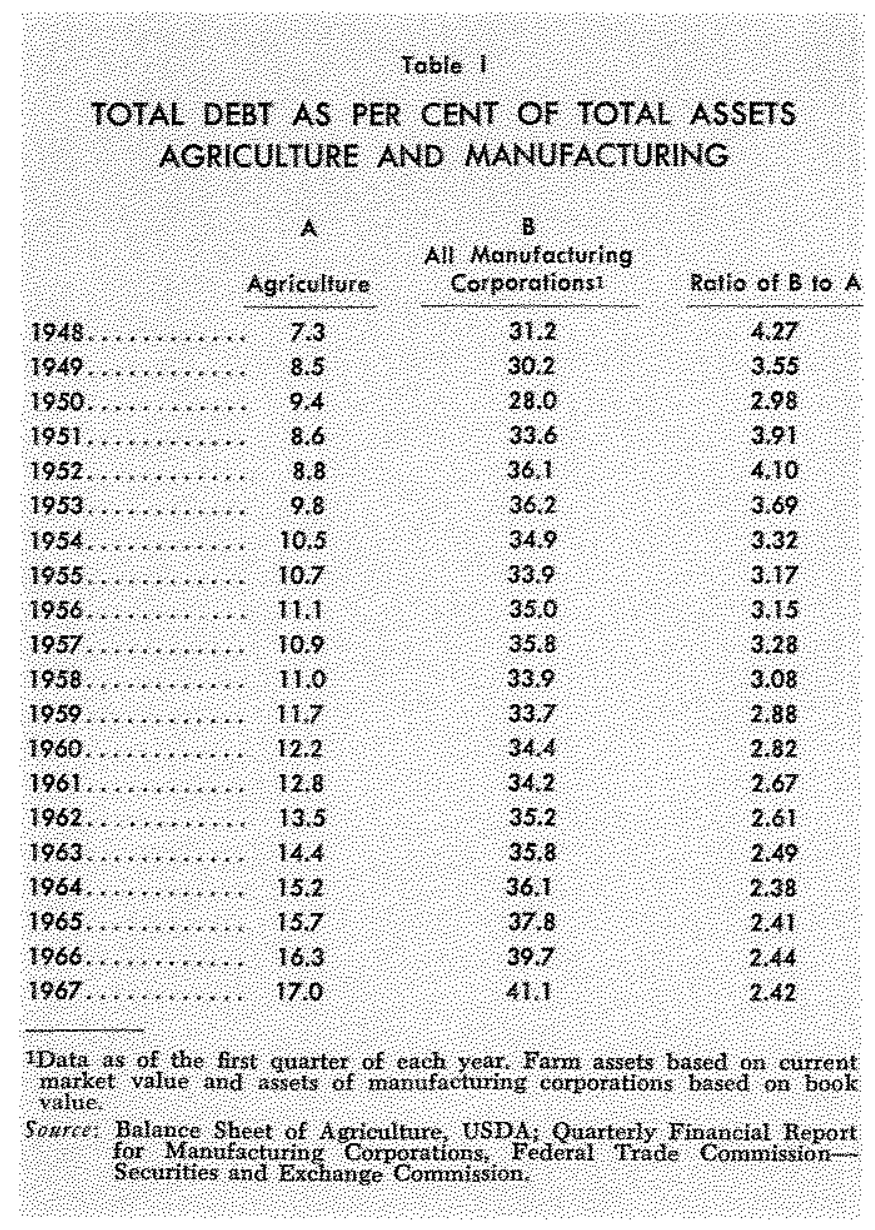


contrasts appear. Significant changes have occurred in both number of competitor groups in the business and the relative portion of farm credit supplied by each group.

\section{Farm Wortyguge Credit}

Prior to the 1900 's, most farm mortgage credit in the United States was supplied by individuals and other noninstitutional sources. A recent study of farm mortgages recorded in Tippecanoe County, Indiana, shows that individuals supplied more than three-fifths of all such credit extended in this county in each of the years 1865-1880, inclusive. In the four years 1865-1868, inclusive, such loans by individuals accounted for more than 90 per cent of the total. ${ }^{1}$ Similar results were obtained in a study of farm mortgage credit in Champaign County, Illinois, for the same period. Individuals supplied more than three-fourths of all such credit in this county during the 16-year period. ${ }^{2}$

Since the turn of the century, a relative decline has occurred in the per cent of farm mortgage credit supplied by noninstitutional lenders. Conversely, the per cent supplied by institutional sources has consistently increased. For example, in 1910 institutional lenders supplied only 25 per cent of the outstanding farm mortgage credit in the nation, while in 1967 the amount supplied had increased to 60 per cent. Despite the recent increase in use of land contracts, which tend to increase seller-financed farm transfers, the per cent of farm mortgage debt held by institutions has remained stable since 1960.

Only two major institutional lender groups, commercial and savings banks and life insurance companies, were in the farm

1 Jay Ladin, "Mortgage Credit in Tippecanoe County, Indiana, 1865 1880 , Agricultural History, fanuary $1967, \mathrm{pp} .37-43$.

2 Robert F. Severson, Jr., "The Source of Morkgage Credit for Champaign County, 1865-1880," Agricultural History, July 1962 , p. 154 . mortgage credit business in 1910 (Table II). With the creation of the Federal Land Banks in 1916 a third major credit supplier entered the field, and in the 1930's the Farmers Home Administration (Farm Security Administration) was created to finance high-risk farm mortgages with Government assistance. The land bank system through sale of bonds provided farmers with another excellent credit pipeline to the nation's financial centers.

Each of the three major groups of financial institutions supplying farm mortgage credit has over the years either held their relative positions or supplied an increasing proportion of the total, except during the Great Depression of the thirties. The Federal Land Banks and life insurance companies, which have better

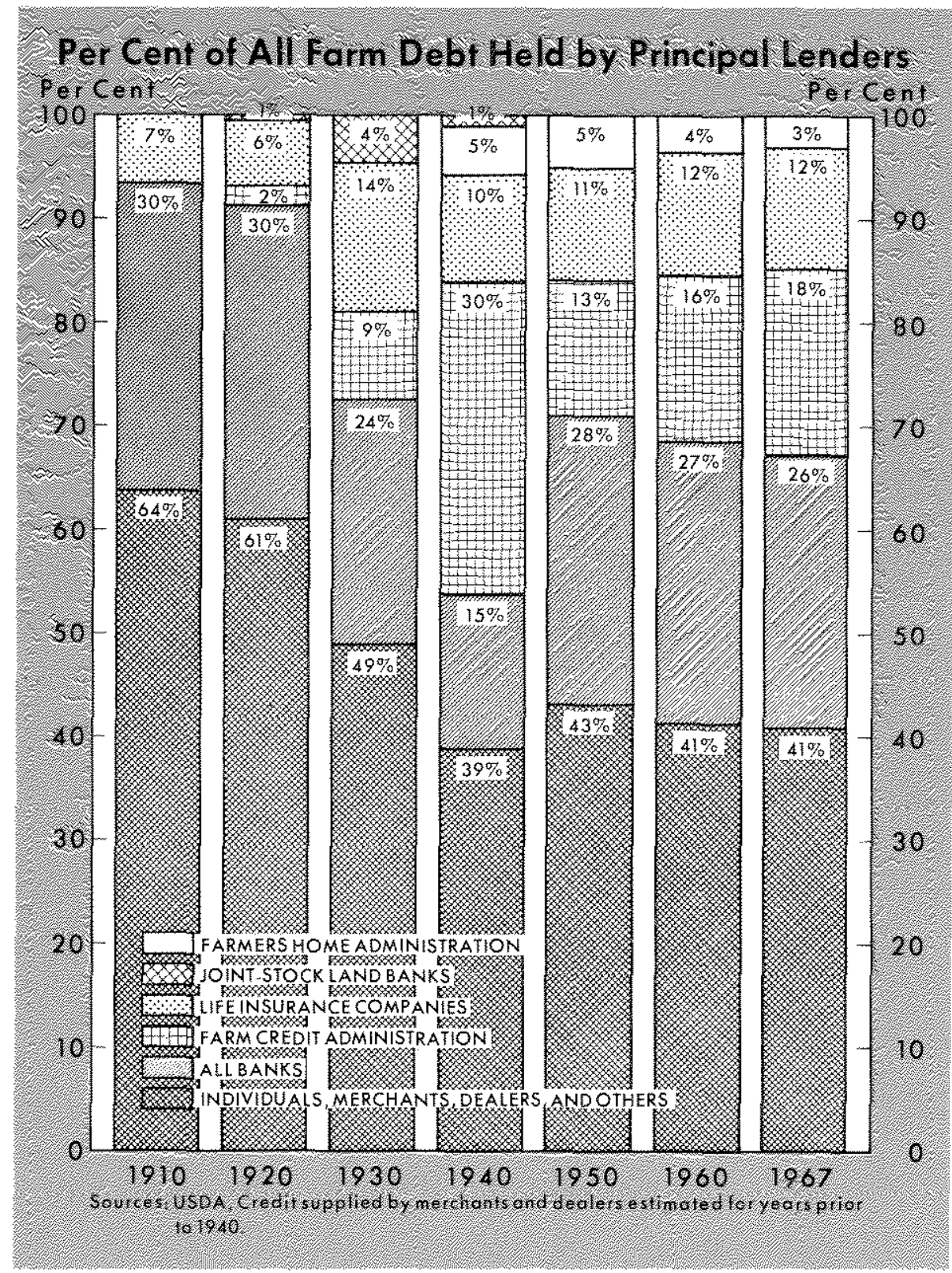




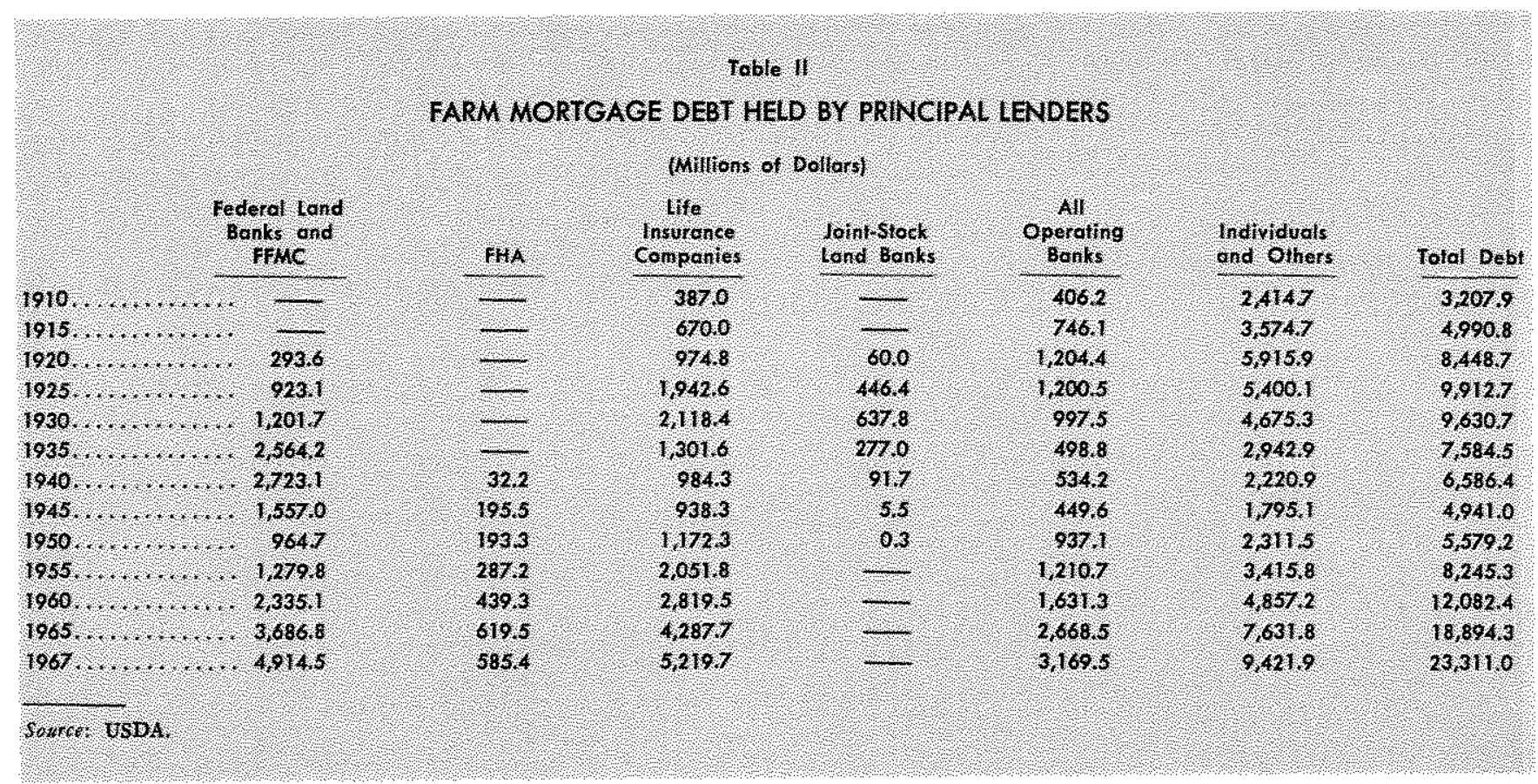

pipelines to financial markets, have supplied relatively larger portions than commercial banks which rely primarily on local funds, and are often short of mortgage credit supplies. The share held by the Land Banks rose steadily from the date of their organization through the 1920 's. With substantial Govermment assistance they undertook emergency mortgage financing in the mid-1930's, and their share rose rapidly. After the liquidation of these loans in the $1940^{\circ} \mathrm{s}$ and early 1950 's, the Land Bank's share again increased and accounted for 21 per cent of the total in 1967. The share held by life insurance companies rose from 12 per cent of the total in 1910 to 22 per cent in 1967. The share held by commercial and savings banks rose from 13 to 14 per cent of the total during the period.

In addition to the expanded role of the three major institutional suppliers of farm mortgage credit, the group listed under the heading of "individuals and others" may have expanded from its composition of earlier years. In the late Nineteenth Century this group was probably composed almost entirely of individual investors, which included primarily relatives and acquaintances of borrowers, and a small number of other individuals. ${ }^{3}$ More recently, however, this group consists of a number of other lenders, including endowment funds of schools, fraternal societies, cemeteries, hospitals, etc. ${ }^{4}$

The evidence thus indicates that the supply side of

3 Severson, Ibid.

4 William G. Murray and Aaron G. Nelson, Agricultural Finance, (Ames, Iowa: Iowa State University Press, 1961), p. 266. farm mortgage credit markets has increased in competitiveness. The number and types of agencies in the business have increased and the geographic area covered by some has been enlarged. Insurance compaw nies and the Federal Land Banks have tapped the national financial markets for farmers, greatly supplementing local sources of farm mortgage funds. Furthermore, both operate on a nation-wide basis. In contrast, prior to the turn of the century the Federal Land Banks had not been created, and the relatively small portion of mortgage credit supplied by insurance companies was limited primarily to the Corn Belt states. Indicative of the more expansive area coverage of insurance loans during recent years are the data on such loans in specific areas. In 1930 insurance companies held less than 0.2 per cent of the farm mortgage debt in the Northeast and less than 8 per cent of the total in the Mountain and Pacific states. In 1967 they held 3.4 per cent of the total in the Northeast and 27.4 and 17.0 per cent, respectively, in the Mountain and Pacific states. ${ }^{5}$

\section{Non}

Non-real estate farm credit supply groups have also increased since 1910. Even to a greater extent than mortgage lenders, this group was dominated by local suppliers well into this century. Local banks, dealers, merchants, and other local sources were almost the only suppliers of such credit prior to the beginning of credit extension by the Federal Intermediate Credit

`USDA, Agricultural Finance. 
Banks and the Farmers Home Administration (emergency crop and feed loans) in the mid-1920's (Table III). In the mid-1930's the Production Credit Associations entered the short-term farm credit supply market and have become a major source of such loans.

It is generally believed that merchants, dealers, and other non-reporting lenders held at least 50 per cent of all non-real estate farm credit prior to the 1940 's. Since early 1940 , however, the per cent of the total held by this group of lenders has declined, and by early 1967 it accounted for only 41 per cent of all non-real estate farm credit outstanding.

Commercial banks have been the largest single institutional supplier of non-real estate farm credit throughout the period since 1910. It is generally believed that banks supplied about 50 per cent of such credit until the 1930's when the Production Credit Associations and the Farmers Home Administration began operations. Following this additional competition, the per cent held by both banks and non-reporting creditors declined. The banks" per cent of such credit fell sharply in the $1930^{\circ} \mathrm{s}$, picked up somewhat in the $1940^{\circ}$ s, held about steady in the 1950's, and has declined somewhat since 1960 .

Similar to movements in farm mortgage credit, suppliers of non-real estate farm credit have probably become more competitive in recent decades. Since the early 1930's one major supplier, the PCA's, which can tap the nation's financial markets through the Inter-

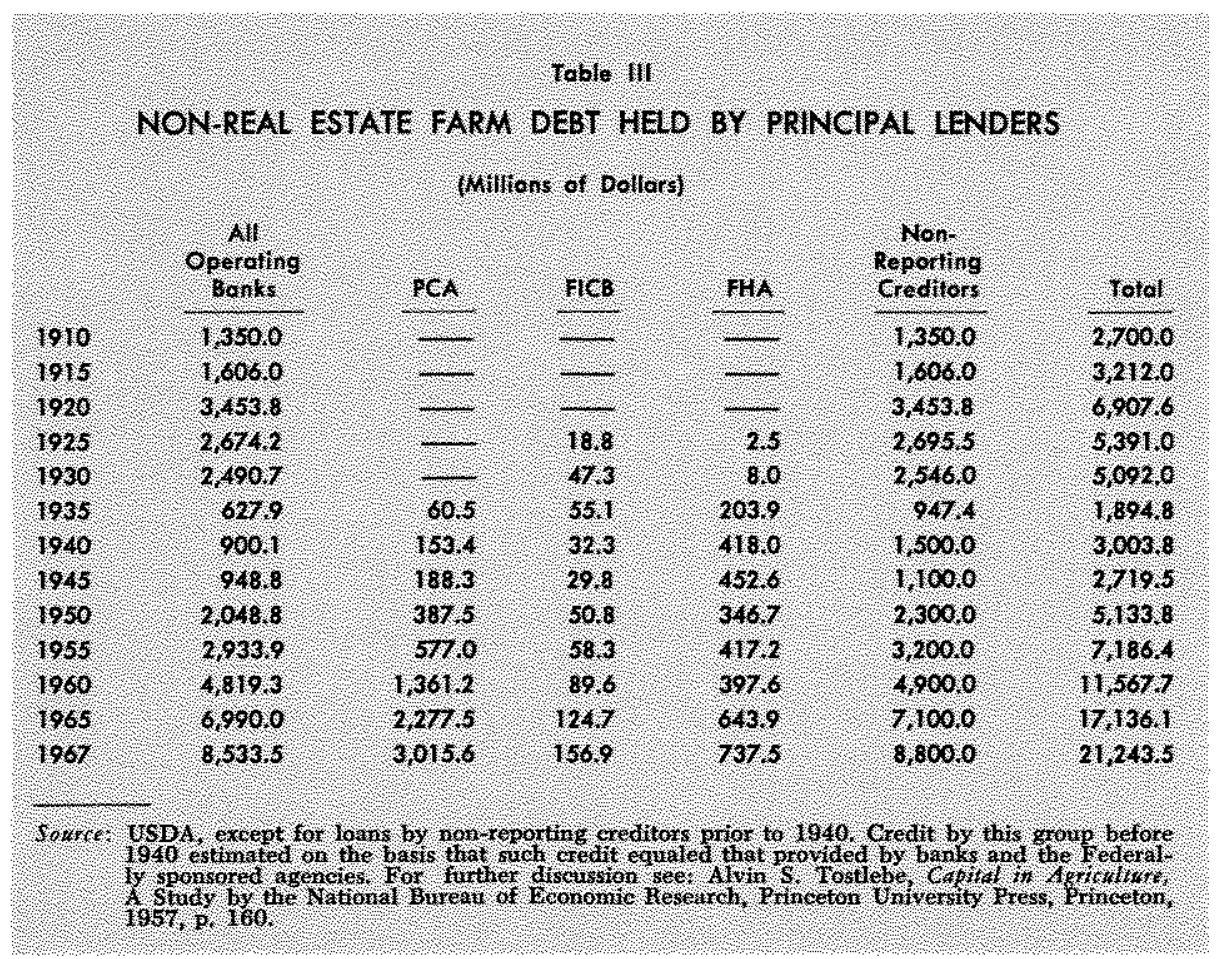

mediate Credit Banks, has been added to the credit source group. The Farmers Home Administration has been created to finance the high-risk credit demand with government assistance. In addition, numerous agribusiness corporations with great financial backing have entered the farm financing field in the merchantand-dealer category in order to enhance sales of farm supplies. These additions have broadened both the number of opportunities for farmers to obtain shortterm credit in any locality and the areas in which such funds can be assembled for farm use.

A combination of farm mortgage credit and non-real estate farm credit further points up the changes in farm credit supplies. On the basis of estimates for merchant and dealer credit, which probably understate the amount of such credit in the earlier years, noninstitutional credit to farmers has declined relative to the total, from 63.7 per cent in 1910 to 40.9 per cent in 1967. This relative decline has been fairly consistent, except for a few years immediately following World War II when the public had an abundance of liquid assets, and since 1960, a period of rapid expansion in the contract selling of real estate which tends to enhance seller financing of real estate transfers. Despite the rapid growth of seller-financed farms, which offer sizable tax advantages to the seller, the long-term downswing in per cent of farm credit financed by noninstitutional sources has not been reversed.

Farm credit supplied by the major institutional lenders has, on the other hand, increased in most decades. About 30 per cent of all farm credit was probably supplied by commercial banks during the 1910-20 decade, a declining proportion during the $1920^{\prime} \mathrm{s}$, and a sizable further decline during the first half of the 1930 's. The per cent held by banks rose from the mid-1930's to the early 1950 's and has remained about stable at near the 1910-20 proportion since 1950.

The agencies of the Farm Credit Administration, with the exception of a major bulge during the Depression of the $1930^{\circ} \mathrm{s}$, followed by a sharp contraction in the 1940 's, have shown a fairly consistent gain in per cent of all farm debt holdings. 
Also, insturance companies have increased their proportion of farm debt during most of the decades since 1910.

Most of the relative gain by insurance companies was made by the early $1920^{\circ}$ s when their holdings exceeded 10 per cent of the total. Since then, their share has remained within 10 to 15 per cent of the total.

Following the establishment of the Farmers Home Administration in the early $19300^{\circ} \mathrm{s}^{6}{ }^{6}$ its relative portion of the farm debt gained steadily until the mid-1940's. This agency, designed to provide subsidized credit to low-income farmers, held at its peak over 8 per cent of the total farm credit outstanding. By 1950, however, its share had declined to 5 per cent of the total, and it has not exceeded 5 per cent since that time.

With these data on farm credit trends by the various lending agencies as background, we can summarize farm credit supply developments as follows:

1. Farm credit, like farming itself, is becoming more commercial and less dependent on relative, friend, neighbor, and merchant relationships. Financial institutions currently supply more than 60 per cent of the total, and their portion has generally increased since 1910 , with the exception of a short period following World War II when individuals, merchants, and dealers had excessive quantities of loanable funds.

2. With the entry of more financial institutions into the farm credit business and the relative decline of nonfinancial institutional lending, farm credit supplies have become less personal. This tends toward greater efficiency in the industry. Credit and credit purchased resources will flow to the more efficient users as determined by the impersonal officials of the financial agencies. Those users provide the greatest returns to capital and can more readily repay debts.

3. The closer ties of farm credit to the financial markets, as represented by life insurance companies, the Farm Credit Administration, and to a lesser extent, commercial banks through the correspondent banking system, mean a more reliable supply of farm credit but perhaps greater fluctuations in interest rates. With such ties, credit at some price will probably be available to any farmer in the absence of legal restrictions, provided he meets the usual credit requirements of the lender. The same sources of funds, however, reflect relatively wide interest rate fluctuations, and the credit agencies which rely on such sources must ultimately reflect such rate changes in loans to farmers. In the 6The Resettlement Administration in the early 1930 s later
called the Fam Security Administration. financial markets, interest rates are determined by the demand for and supply of loanable funds nationally. The rate is thus determined by the productivity of such funds in all potential uses, To gain control of such funds the farmer must thus pay the wholesale rate plus the cost of retailing.

4. Farm credit ties to the nation's financial markets assure more uniform interest rates to farmers through. out the nation, given similar lending costs and risks. Prior to these ties, rates paid by farmers may well have been determined by local supply and demand conditions. In such isolated markets, rates may have been greater or less than rates which reflected national credit conditions. With national funds available, however, local areas where rates are relatively high will attract funds from other areas until local and national rates are equalized after allowing for risk and lending costs differentials.

5. I shall also contend that the relative decline of farm credit by nonfinancial institutional groups was not caused by a decline in competition from these groups, but is the result of increased competition for farm debt on the part of the farm credit institutions. As evidence, we have in the Farm Credit Administration one additional source of farm real estate credit (the FLB's) and one additional source of non-real estate credit (the PCA's) available to every potential farm borrower. In addition, the insurance companies have made available farm real estate credit to most potential users in the nation. Evidence also indicates that commercial banks are more aggressive in the farm credit market than during the first quarter of the century, Large numbers of banks have hired agriculturally trained men to head farm departments. These men are specially trained for making credit available to farmers. Also, most banks now have substantial non-farm deposits to draw on for farm lending purposes. Such accounts are more stable seasonally than accounts originating in primarily farming communities. Thus, larger credit supplies are available for farm use during the seasonal shortage of farm deposit accounts. Banks also have better arrangements with city correspondents and other outside sources such as insurance companies to draw on for overlines, real estate credit, or general credit shortages.

What is the meaning of these developments to merchant and dealer credit suppliers? I believe that most farm credit demands are being adequately met at competitive rates. If good credit-risk farmers are already receiving adequate credit supplies, extensive gains in merchant and dealer credit is unlikely, except at great risks. I would suggest that for such credit to succeed over the longer run, it must meet the following tests: 
1. It must be made on a sound basis through proper credit analysis by a credit expert and not primarily by sales persomnel.

2. Such credit, if tied to the sale of a particular farm input, must not create an imbalance in the farming operation. Given the fact that most farms are eligible for a limited amount of credit, if excessive amounts are used for one purpose, leaving insufficient amounts for other purposes, the excess may cause the farm to be inefficient. Thus, such credit that causes an imbalance in the farming operation may ultimately lead to failure.

3. The provision of merchant and dealer credit must be made on an efficient basis. If nonfinancial groups can supply credit as efficiently as the financial agencies, healthy competition can be maintained. On the other hand, loanable funds are a scarce resource and cannot be supplied without costs by any lender. Funds must ultimately be purchased from savers, excluding the small increments added through monetary actions. The retailing of funds also requires a margin. Such costs must be eventually covered by rates charged or $a b-$ sorbed in the price of goods sold. Thus, the test for who gets the credit supply business will be determined by who can purchase and sell funds most efficiently.

4. Farming is now being done on narrower margins than formerly, and risks are greater. In 1965 purchased inputs and other expenses amounted to more than three-fourths of total farm product sales. As indicated earlier, debt exposure is also greater. With the narrow margin of profit and the inability of the farmer's own and unpaid family labor to absorb the losses on modern, high-capacity farms, attention must be focused on the reliability of credit analysis. Under these conditions, success in the farm credit business is not likely to be attained through all-out exertions to build up volume alone, but through a combination of sufficient volume of business to achieve efficiency and wise selection of risk to avoid excessive losses and collection costs.

In summation, agriculture has historically been financed internally. Credit has accounted for only a small proportion of total capital. Credit as a proportion of farm assets has, however, steadily increased in recent decades. With the rising demand for farm credit new specialized farm credit agencies have been developed, and a further expansion of the other financial agencies which were already in the field has occurred. With these developments credit supplied by the noninstitutional groups such as merchants, dealers, and individuals has declined relative to the total. I believe that this decline is the result of more intensive competition in the farm credit business rather than a voluntary withdrawal of the individual, merchant, and dealer group.

Now let's return to a portion of my original subject, "How can businessmen influence the paying habits of farmers?" First, I shall reiterate that there is no substitute for good credit analysis. The soundness of the credit extended is the most important factor in determining whether or not it will be repaid. I believe that the repayment habits of farmers or any other group are more likely to be associated with the individuals selected and the soundness of their business operations than with other means which may be devised. Second, farm credit customers are not operating in isolation of financial markets. The good credit-risk farmers could probably obtain credit from several sources prior to becoming customers of merchants and dealers. Third, I suggest again the possibility of over-selling some inputs to some farmers and thereby causing a profitable farm to become unprofitable. Such a condition is beneficial to neither lender nor borrower.

If merchants and dealers adhere to these credit principals, they will probably continue to be a major competitor in supplying farm credit. Now that most merchants and dealers represent corporations which have connections with the major money markets, they can become a major vehicle for moving funds from surplus to deficit areas, thereby performing a valuable service for farmers and the financial markets. In addition, if the credit is profitable to both lender and borrower, more efficient use of resources is achieved and total welfare is enhanced.

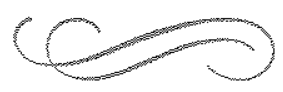

